\title{
The Problems and Countermeasures of High-tech Enterprises' Financing
}

\author{
Huining Zeng \\ School of Economics and Management \\ Nanjing University of Science and Technology \\ Nanjing, China
}

\begin{abstract}
High-tech enterprises are knowledge-intensive, technology-intensive economic entities and the main body of scientific and technological innovation. Its development is mainly driven by innovation. It is the fundamental driving force for improving the capability of independent innovation and building an innovative country, and it is of great significance to the development of the national economy. Under the new normal of economy, the development of high-tech enterprises is also an inevitable choice for China to seek reunification between economic development and environmental protection. Due to the characteristics of high-tech enterprises themselves and external environment factors, enterprises are generally faced with the problem of financing difficulties, and even affect and restrict the further development of high-tech enterprises. Therefore, it is of great significance to solve the financing problem of high-tech enterprises. This paper introduces the overview of high-tech enterprises and their financing, analyzes the problems and causes of their financing, and proposes countermeasures and suggestions for solving the financing problems of high-tech enterprises.
\end{abstract}

Keywords-high-tech enterprises; financing problems; countermeasures and suggestions

\section{INTRODUCTION}

Since the reform and opening up, China's economy has developed rapidly and has become the second largest economy in the world after the United States. At the same time, it also left behind such problems as over-exploitation of resources and serious environmental pollution. In order to solve and mitigate the problems left over from the development of more than 30 years, China has timely proposed the economic new normal and innovation-driven development strategy. And the development of high-tech enterprises is mainly driven by innovation. It produces the products with high added value by relying on new technologies and new materials, which is in line with the background of driven by innovation-driven development. It is the fundamental driving force for improving the capability of independent innovation and building an innovative country. Meanwhile, it is also an important sign to measure a country's overall national strength and international competitiveness. However, due to their own characteristics and external environment factors, many high-tech enterprises in China are generally faced with difficulties in financing, which restricts their development to a large extent. Therefore, it is necessary to strengthen the research on its financing issues and find the corresponding solutions to promote the rapid development of enterprises. This paper mainly uses the literature research method. Through reading a large number of journals and books to understand the issues related to financing of high-tech enterprises, understand the financing problems and causes of the enterprises, and put forward the corresponding countermeasures and suggestions for solving their financing problems.

\section{HIGH-TECH ENTERPRISES AND FINANCING}

\section{A. The Definition and Characteristics of High-tech Enterprises}

High-tech enterprises are new and modernized enterprises which rely on new technologies and new materials, have hightech talents, need a lot of R\&D capital, carry out continuous research and development and technological achievements transformation, and eventually produce high-tech products. They have the following characteristics:

The first is high risk and high yield. According to statistics, China's national scientific and technological achievements are more than 30000 annual, but $80 \%$ of them have not been converted into products, which indicates that enterprises have great technological risks in the research and development process. A small portion that converts into a product faces a higher market risk due to it is difficult to grasp the market demand and consumer purchasing power. These risks make it hard for high-tech enterprises to raise funds through banks or issuing bonds. A small number of banks that provide loans to enterprises will ask for higher borrowing rates in order to reduce their own risks, which makes high-tech enterprises face higher operating risks. If the enterprises are insolvent, it will be difficult to survive and it will more difficult to develop further. Generally speaking, high risks correspond to high returns. In today's era, once the research and development achievements are successfully transformed into products and are popular in the market, then enterprises will obtain substantial returns and it is beneficial to the further development of enterprises.

The second is high input. High-tech enterprises adopt the innovation-driven model of technological innovation, which is less dependent on natural resources compared with traditional enterprises. Meanwhile, it is in line with the principle of environmental protection economic development. It is based on new technologies and new materials and is engaged in 
continuous scientific and technological research and development, which requires a large amount of time and money, as well as the introduction of comprehensive technical personnel. With the deepening of technology research and development, the amount of funds it invests will gradually increase. What's more, the input of human resources, material, and time will also be long-term.

The third is that the intangible is important. High-tech enterprises first have research achievements and then realize production. They have independent intellectual property rights, patents and other intangible assets, and intangible assets account for a large proportion of total assets. For example, the cost of raw materials for a semiconductor chip is less than $20 \%$ of its research and development costs. Therefore, the survival and development of a high-tech enterprise depends a large extent on the quantity and quality of its intangible assets.

\section{B. Different Development Cycles of High-tech Enterprises Have Different Financing Characteristics}

In the initial stage, high-tech enterprises are mainly engaged in the research and development of technology. Through the research and development of technical personnel, the general shape of the products or the development of samples are formed. At this stage, the enterprise is just at the beginning, and there is no product and not market for sales, so the enterprise will not have cash inflows. At this stage, there is only funds' input, and most of the funds are obtained by the partners of the enterprises through self-raising, and there is almost no inflow of external funds.

During the start-up period, enterprises begin trial production of samples and enforce market development. The enterprises engage in publicizing extensively to understand the market demand and consumers' purchasing power, as well as further improve the product design and performance to meet the market demand, which lays the foundation for the development of the enterprises. At this stage, the production of products and further research and development need to increase the investment of funds. However, the funds obtained through self-raising can no longer meet the capital requirements for the development of enterprises. In addition, due to the company's operating income is small, cannot meet the criteria for the recognition of high-tech enterprises, and therefore cannot enjoy the country's financial subsidies. Commercial banks are also reluctant to provide loans to them in order to avoid greater risks. Therefore, most enterprises only rely on venture capital at this stage.

During the growth period, the products of the enterprise occupy a certain share in the market, and the enterprises also form a certain scale. Thus, the enterprises can enjoy the preferential policies granted by the state. With the maturity of enterprise technology research and development, the company's operating income also increases gradually, which can make up for the expense incurred in the early stage of research and development. At the same time, banks are also willing to provide loans and other financial support for enterprises with good development prospects. Therefore, the financing method of this stage is an organic combination of internal financing and external financing.
In the mature period, enterprises have been widely recognized by society in all aspects of technology, products, and services. The market share of the products developed in the early stage has gradually increased, the revenue has also stabilized, and the operating risk has also reduced to the lowest level. Therefore, the financing is relatively easy in this stage. At this stage, the enterprises can take advantage of advantages accumulated in the early stages of development to issue stocks in the capital market for direct financing. Thus, they can further strengthen the investment in technology research and development, develop new products and create new values for the enterprises. In general, high-tech enterprises' financing methods are more diversified in the mature period.

\section{PROBLEMS AND CAUSES OF THE FINANCING OF HigH- TECH ENTERPRISES}

\section{A. Government Support Is too Small and Insufficient}

In China, the government mainly supports the development of enterprises by providing enterprises with tax incentives and financial subsidies. The investment in $R \& D$ expenditures has been increasing year by year, but it is far from meeting the needs of most enterprises. Generally speaking, in the initial stage and during the start-up period, the enterprises' products are in the initial of research and development, and there is great uncertainty in market sales. In addition, the inflow of cash is relatively small and there are relatively large technical and market risks. It is difficult for enterprises to obtain loans from banks. At this stage, enterprises urgently need the government to provide financial support to help them complete a series of production and operation activities such as such as trial production and market development. However, due to the scale of government support is too small, and those enterprises that fail to meet the standards of high-tech enterprises but have good projects will not be able to enjoy the government's tax incentives and financial subsidies. In contrast, for enterprises those are eligible to receive the government's financial support, due to the total amount of funds provided by the government is insufficient, which cannot meet the needs of enterprises' development. In addition, the government has complicated procedures for providing financial support, which requires a long time for approval. In a word, the government cannot provide funds for the enterprises in time and might delay the time for technology research and development. In the era of technological development, it is possible that enterprises will fail to meet the market demand timely after the success of technological research and development, and face the risk of being eliminated by the market.

\section{B. Financing Channels Are Single}

High-tech enterprises have low technology conversion rate in China. What's more, when the product enters the market, enterprises face great uncertainty in the revenue, higher technology and market risks, less cash inflows, weaker profitability, which indicates the needs of the enterprises' development can't only rely on the internal financing. In fact, most enterprises rely mainly on external financing. External financing is mainly through loans to banks, but it is very difficult for enterprises to make loans to banks. First of all, the 
information between banks and enterprises is asymmetric and the high technical risk and market risk of high-tech enterprises, which makes the value of their research and development technologies is difficult to be recognized by banks. Second, the credit management system of high-tech enterprises is not perfect, so banks cannot accurately grasp the financial status of enterprises and evaluate the solvency of enterprises. In order to reduce their own risks and account for the safety of funds, banks are reluctant to provide loans to high-tech enterprises. In contrast, banks are more willing to provide loans to enterprises with collateral as a security due to the requirements of security and robustness. However, the assets of high-tech companies are mainly intangible assets, and they lack tangible assets that can be used as collateral, so it is difficult for them to obtain loans through mortgage. Even if the loan is obtained, the amount of money is too small to meet the needs of enterprises' development.

\section{Intellectual Property Pledge Financing Starts Late}

Intellectual property pledge financing can better meet the needs of enterprise financing, but this financing method is still in the initial stage of exploration and faces many obstacles. First, the intellectual property value evaluation system is imperfect and lacks authority. There is a certain value risk of intellectual property from the perspective of the banks. For the sake of robustness, banks tend to underestimate the value of intellectual property and even refuse to provide loans to companies through intellectual property pledges. Second, the legal system related to intellectual property pledge financing is not perfect. Third, the trading market of intellectual property is not yet perfect. Intangible assets such as intellectual property have poor liquidity and are not easily realized compared with tangible assets.

\section{The Capital Market System Is Imperfect}

First, financing of venture capital is difficult. Venture investment in China starts late, less number of venture capital funds, and the intermediaries are not perfect. Moreover, unlike physical investment, risk investment cannot be accompanied by the growth of a company for a long time and it will withdraw from the enterprise after gaining profits during the period of the enterprises' development. This method cannot effectively help enterprises solve financing problems in the short and long term. At the same time, there are many problems in the withdrawal mechanism of venture capital. Second, it is difficult to obtain listing financing. China's capital market is divided into the main board and the growth enterprise board. The listing conditions of the main board market are relatively high. As China's high-tech enterprises start late and are small in scale, it is difficult to reach the listing conditions of the main board, so it is difficult to conduct stock financing through the main board market. In order to allow high-tech enterprises to be able to finance through the capital market, China timely launches the growth enterprise board. Although the listing conditions of the growth enterprise board are relatively low compared with the main board, for most enterprises, the conditions for listing financing are still very high. In fact, only a few high-tech enterprises are eligible for the conditions for listing financing.

\section{COUnTERMEASURES AND SUGGESTIONS TO SOLVE THE FINANCING PROBLEMS OF HIGH-TECH ENTERPRISES}

Science and technology are the primary productive forces that change our production methods and lifestyles. After the party's 18th National Congress, the new leaders of the Party Central Committee in combination with the actual situation of China's development put forward the new economic normality and encourage enterprises to change their development methods. High-tech enterprises as the core of achieving innovation-driven development should shoulder a major historical change mission and are the main driving force of the current economic development. As we all know, the development of high-tech enterprises cannot be separated from the support of funds. At present, financing difficulties have seriously affected the rapid development of high-tech enterprises. The financing difficulties are caused not only by enterprises, but also by external factors such as the government and banks. Therefore, it is imperative to propose corresponding solutions and suggestions according to the problems and causes of the financing of high-tech enterprises.

\section{A. Increase Government Support and Set up Special Development Funds}

The government provides financial support to high-tech enterprises with good market prospects and potential competitive by establishing a special development fund. Due to the government's propaganda on taxation, financial subsidies and other related preferential policies is not enough, many high-tech enterprises do not understand preferential policy and select the projects blindly. As a result, the projects fail to meet the conditions of enjoy policy-related subsidies. In view of this situation, the government should set up an information service platform for high-tech enterprises and adopt various forms such as internet, newspapers, and teleconference to conduct policy publicity. For high-tech enterprises with the idea of listing, relevant departments should play a role in providing them with related policies and market information.

\section{B. Improve the Management Level of enterprises and Establish a Sound Financial Service System}

In China, the development of high-tech enterprise starts late and the scale is small, its financial management system is not perfect and the consciousness of active disclosure of information is not strong, which results in there is information asymmetry between banks and enterprises. In the face of this situation, high-tech enterprises should improve their own management level. First, enterprises should introduce both technical personnel and enterprise management personnel. Second, enterprises should set clear financial management goals and improve the internal control system. Third, enterprises should increase their awareness of information disclosure and actively disclose the company's assets and profitability, so that banks can effectively and accurately assess the company's business risks and solvency, and try to avoid information asymmetries between banks and enterprises. Hightech enterprises with high risks and insufficient collateral, it is difficult to obtain loans from banks. For this situation, on the one hand, the government should formulate relevant laws and regulations, strengthen the supervision on the legality and 
fairness of the financial statements of enterprises, and ensure the authenticity of financial statements. On the other hand, the government should establish government-funded credit guarantee institutions. As the intermediary between banks and enterprises, the government can not only guarantee banks against credit risks, but also ensure that enterprises can obtain the loans they need. Meanwhile, in the context of financial innovation, financial institutions are encouraged to provide diversified financial services. It is necessary that establish the specialized financial institutions for high-tech enterprises. Those financial institutions should formulate corresponding loan fund and interest rates by combining with the financial characteristics of enterprises' different stages. In addition, the financial institutions should reflect the differentiation between the loans of high-tech enterprises and other loans.

\section{Further Explore and Promote Intellectual Property Pledge Financing}

China's intellectual property pledge financing is still in the pilot stage. It is difficult for the bank to assess the value of intellectual property. In addition, the risk for the banks is too high to be willing to carry out the business. We can introduce guarantee agencies or provide guarantees directly by the government to share the risks borne by the banks. At the same time, the government should guide and encourage banks to carry out this business, improve the intellectual property value evaluation system, improve the authority and fairness of the assessment results, improve the intellectual property trading market, and promote intellectual property pledge financing.

\section{Build a Multi-level Capital Financing System}

Venture investment is an important method of direct financing for high-tech enterprises in China. It can provide financial support for enterprises in the initial stage of development, and avoid enterprises giving up research and development due to the break of capital chain. China's venture investment is still in its infancy. The government should establish institutional guarantees for venture investment, improve the exit mechanism, and create a good financing environment for enterprises to meet their financing needs in different periods. In view of the difficulty of corporate listing and financing, China has launched the growth enterprise board in the capital market. Although the development of the growth enterprise board is not yet perfect, the growth enterprise board can better provide direct financing for high-tech enterprises that meet the listing conditions. Therefore, China should fully tap the potential of the growth enterprise board and provide financial support for more high-tech enterprises.

\section{CONCLUSION}

High-tech enterprises are important standards for measuring a country's comprehensive national strength. At present, China is in a critical period of changing the mode of economic development, and high-tech enterprises also shoulder the important mission of historical change. The difficulty in financing hinders the development of high-tech enterprises. Governments, financial institutions, enterprises and the like should make active efforts, collaborate with each other, explore together, and find an effective way to solve the financing problems of high-tech enterprises. In a word, it's very important to promote the rapid and healthy development of enterprises.

This paper is based on the idea of proposing, analyzing and solving problems and adopts literature research methods. First, this paper identifies the definition and characteristics of hightech enterprises. Second, this paper introduces the characteristics of enterprise financing in different periods and the financing strategies of enterprises in different periods. Third, this article analyzes the problems and causes of financing in high-tech enterprises. Finally, this paper proposes countermeasures and suggestions for solving enterprises' financing problems by combining with the current economic development status in China, which can be used by relevant parties.

\section{REFERENCES}

[1] Zhao Xue, High-tech enterprises' financing difficulties and countermeasures, Modern Economic Information, 2013(12), pp.297-298.

[2] Zhang Yunfeng, Analysis on financing path of China's high-tech enterprises, Economic Forum, 2016(1), pp.68-71.

[3] Qin Ping, Wang Xia and Lin Yanxue, Analysis on financing channels of high-tech enterprises in growth period, Research of Finance and Accounting, 2012(2), pp.53-55.

[4] Wang Qian, Research on financing problems of high-tech enterprises in China, Shanxi: Shanxi University of Finance and Economics, 2012.

[5] Wang Haixia, Li Yuan and Fan Yiran, Research on financing of private high-tech enterprises in Beijing - analysis based on questionnaire, Research of Finance and Accounting, 2015(1), pp.21-23.

[6] Liang Zhuo and Cao Liping, Research on Financing Problems of Hightech Enterprises, Modern Business Trade Industry, 2013(16), pp.102103.

[7] Shen Wenwen, A summary of international comparison of investment and financing of high-tech industry, China Collective Economy 2015(18), pp.86-87.

[8] Yan Xuemei, Several Financial Management Issues in High-tech Enterprises' Financing Process, Times Finance, 2015(3), pp.64-65.

[9] Huang Hongbin and Yuan Zeming, Problems and causes of intellectual property financing in China's high-tech enterprises, Special Zone Economy, 2011(8), pp.248-249.

[10] Han Feng, Cao Yang and Zhang Xiaoming, GEM Market - An Effective Way to Solve the Financing Problems of High-tech SMEs in China, Social Scientist, 2005(1), pp.337-338.

[11] Feng Xiaoqing, Research on the pledge of intellectual property in China and its improvement countermeasures, Hebei Law Science, 2012(12), pp.39-46.

[12] Wang Lei, Discussion on Promoting Pledge Financing of Intangible Assets in China, Financial development research, 2009(3), pp.87-88.

[13] Cao Zhou, The practice and enlightenment of foreign government to promote the financing of high-tech enterprises, China Business and Market, 2008(16), pp.74-76.

[14] Fu Lanjun, Financing problems and solutions for China's high-tech industry, Modern Economic Information, 2014(14), pp.329.

[15] $\mathrm{Hu}$ Zhenhua, Wang Yan and Li Yapei, Financing difficulties and countermeasures for high-tech enterprises in Hainan province, Hainan Finance, 2007(12), pp.27-30.

[16] Zhu Jing, Discussion on the financing problem of high-tech enterprises in the growth stage, Jiangxi: Jiangxi University of Finance and Economics, 2014. 